\title{
EFEKTIVITAS TEKNIK PURSED LIPSBREATHING PADA PASIEN PENYAKIT PARU OBSTRUKSI KRONIK (PPOK): STUDY SYSTEMATIC REVIEW
}

\author{
1| Barakatul Qamila, 2| Maria Ulfah Azhar, 3| Risnah, 3| Muhammad Irwan \\ Email Korespondensi : barakatul.qamilah@gmail.com \\ Universitas Islam Negeri Alauddin Makassar, Indonesia
}

\begin{abstract}
Chronic obstructive pulmonary disease (COPD) is one of the chronic diseases characterized by limited air flow contained in the respiratory tract. Breathing shortness becomes the main complaint feeling by COPD patients. Pursed lips breathing (PLB) technique can increase pulmonary compliance to retrain the respiratory muscles to function properly and prevent respiratory distress. This study aims to determine the effectiveness of pursed lips breathing technique in COPD patients. The research used a quantitative descriptive design with a systematic review approach. There were 315 articles published from 2015-2019. From 315 articles, 7 articles that met the inclusion criteria and research questions. Based on the result of the Systematic Review that has been conducted on pursed lips breathing technique in COPD patients, it was concluded that the PLB technique is effective to reduce breathing frequency and improve oxygen saturation. PLB technique given 3 times per day in every morning, afternoon, and evening with a time of 6-30 minutes for 3 consecutive days. The PLB technique is effective in reduce frequency respiratory and increase oxygenation in COPD patients with ineffective breathing patterns. Furthermore, it is suggested that PLB techniques can be applied as one of the nurses' independent interventions in nursing care for COPD patients to reduce patients complaints of breathing shortness.
\end{abstract}

\begin{abstract}
Abstrak
Penyakit paru obstruksi kronik (PPOK) merupakan salah satu penyakit kronik yang ditandai dengan terbatasnya aliran udara yang terdapat di dalam saluran pernapasan. Sesak napas menjadi keluhan utama yang dirasakan oleh pasien PPOK. Teknik pernapasan pursed lips breathing (PLB) merupakan teknik pernapasan yang membantu meningkatkan compliance paru untuk melatih kembali otot pernapasan berfungsi dengan baik serta mecegah distress pernapasan. Penelitian ini bertujuan untuk mengetahui efektivitas teknik pursed lips breathing pada pasien PPOK. Penelitian menggunakan desain deskriptif kuantitatif dengan pendekatan systematic review. Terdapat 315 artikel yang dipublikasi dari tahun 2015-2019. Dari 315 artikel 7 artikel yang sesuai dengan kriteria inklusidan pertanyaan penelitian, dimana kriteria inklusi tersebut ialah artikel tahun 2015-2019 full text yang sesuai dengan topik penelitia yaitu teknik PLB pada pasien PPOK, terdapat ISSN dan atau DOI, artikel yang berfokus pada intervensi terapi Pursed Lips Breathing, artikel yang berfokus pada pemenuhan oksigenisasi dan frekuensi pernapasan sebagai alat ukur. Berdasarkan hasil Systematic Review yang telah dilakukan tentang teknik pursed lips breathing pada pasien PPOK disimpulkan bahwa teknik PLB efektif menurunkan frekuensi pernapasan dan meningkatkan pemenuhan oksigenisasi dalam tubuh. Dengan demikian pemberian latihan yaitu $3 x$ sehari setiap pagi, siang, dan sore dengan waktu 630 menit selama 3 hari berturut-turut. Teknik PLB efektif dalam menurunkan frekuensi pernapasan dan meningkatkan pemenuhan oksigenisasi pada pasien PPOK dengan pola napas tidak efektif. Selanjutnya, disarankan teknik PLB dapat dijadikan sebagai salah satu intervensi mandiri perawat dalam melakukan asuhan keperawatan pada pasien PPOK untuk mengurangi keluhan sesak.
\end{abstract}

\section{Kata Kunci: PPOK; Frekuensi Pernapasan; Teknik Pursed Lips Breathing; Oksigenisasi}




\section{PENDAHULUAN}

Data WHO (1), menyatakan bahwa PPOK telah mengakibatkan lebih dari 3 juta orang meninggal dunia pada tahun 2012 atau sebesar 6\% dari total kematian di dunia pada tahun tersebut. Penyakit paru obstruksi kronik (PPOK) adalah suatu keadaan kegawatdaruratan yang dapat menyebabkan kematian pada penderita dimana kematian dengan penyebab tersebut menempati urutan nomor tiga di dunia setelah penyakit kardiovaskuler dan kanker (2).

PPOK merupakan salah satu penyakit kronik yang ditandai dengan terbatasnya aliran udara yang terdapat di dalam saluran pernapasan. Penderita PPOK di dunia memiliki jumlah yang sangat tinggi sehingga pada tahun 2020 PPOK diperkirakan menempati urutan kelima penyakit yang akan diderita di seluruh dunia (3). Peningkatan angka kejadian PPOK disebabkan karena penuaan penduduk serta paparan factor resiko PPOK (4)

Data Riset Kesehatan Dasar (Riskesdas) (2012) menyatakan bahwa PPOK merupakan penyakit yang menempati urutan ke empat penyebab kematian di Indonesia. PPOK menjadi urutan pertama pada kelompok penyakit paru di Indonesia dengan angka kesakitan (35\%). Prevalensi PPOK tertinggi terdapat di Nusa Tenggara Timur (10,0\%), dan Sulawesi Selatan pada urutan ke tiga $(6,7 \%)(5)$.

Data dari Profil Dinas Kesehatan Provinsi Sulawesi Selatan menyatakan PPOK merupakan penyebab kematian tertinggi penyakit tidak menular berbasis rumah sakit di Sulawesi Selatan yang berjumlah 43 kasus. PPOK merupakan suatu penyakit yang proses perkembangan penyakitnya secara perlahan-lahan dan gejala yang ditimbulkan akan semakin memburuk karena adanya obstruksi saluran pernapasan (6). Penyakit ini dapat dicegah dan meringankan gejala yang ditimbulkan apabila pasien diberikan pengobatan dan diberikan program pelatihan yang tepat (4).

PPOK dapat mengakibatkan gangguan pada proses oksigenisasi keseluruhan anggota tubuh karena adanya kerusakan pada alveolar serta perubahan fisiologi pernapasan. Kerusakan dan perubahan tersebut dapat menyebabkan inflamasi pada bronkus dan mengakibatkan terjadinya kerusakan pada dinding bronkiolus terminalis serta menimbulkan obstruksi atau penutupan awal fase eksprirasi sehingga terjadi keterbatasan saluran nafas yang tidak sepenuhnya reversible yang berhubungan dengan respon inflamasi (4).

Upaya pencegahan dan mengurangi gejala yang timbul pada penderia PPOK dapat dilakukan dengan cara pengobatan farmakologis, dimana pengobatan tersebut bersifat jangka panjang. Selain pengobatan farmkologis, terdapat pengobatan nonfarmaklogi yang dapat dilakukan oleh tenaga kesehatan dan juga oleh diri penderita itu sendiri, dimana perawatan tersebut diperoleh dari edukasi dan latihan yang telah diajarkan oleh tenaga kesehatan salah satunya perawat. Program latihan pernapasan yang dapat diberikan pada pasien PPOK salah satunya ialah metode pursed lips breathing exercise, teknik ini saangat mudah untuk dipraktekkan dalam keseharian pasien (7). 
Pursed lips breathing exercise merupakan program latihan yang diterapkan pada pasien PPOK yang bertujuan untuk mengatur dan memperbaiki pola dan frekuensi napas sehingga mampu mengurangi penumpukan udara atau air trapping, mengurangi sesak napas serta mengkoordinasi frekuensi napas dengan memperbaiki ventilasi alveoli dan pertukaran gas dalam paru-paru.Pursed lips breathing exercise mampu memperbaiki ventilasi dan aliran udara serta memperbaiki volume paru penderita PPOK apabila latihan tersebut dilakukan secara teratur (8).

Pursed LipsBreathing ialah latihan pernapasan yang bertujuan untuk mempermudah proses pengeluaran udara yang terjebak di dalam paru-paru dengan cara membantu melakukan penekanan pada proses ekspirasi. Penelitian nonfarmakologi dalam upaya mengurangi keluhan pada pasien PPOK telah banyak dilakukan salah satunya teknik PLB, tetapi intervensi-intervensi non-farmakologi tersebut masih kurang diketahui oleh pemberipelayanan kesehatan khususnya perawat serta kurang diketahui oleh penderita maupun keluarga pada umumnya. Keefektifan intervensi tersebut perlu dipublikasikan secara global sehingga intervensi PLB ini dapat diterapkan untuk peningkatan taraf kesehatan dan penurunan gejala pada pasien PPOK. Intervensi PLB juga perlu di bandingkan dengan intervensi lain untuk melihat tingkat keefektivan masing-masing intervensi serta tingkat kemudahan dalam menerapkannya, sehingga penulis ingin membahas tentang Efektivitas Teknik Pursed Lips Breathing pada pasien PPOK dengan pendekatan Systematic Review.

\section{METODOLOGI PENELITIAN}

Penelitian ini menggunakan desain deskriptif kuantitatif dengan pendekatan systematic review. Pencarian literatur melalui database : PubMed, ScienceDirect, GoogleSchoolar, dan IJSR (International Journal Science and Research) dengan pertanyaan penelitian terstruktur menggunakan metode elektronik PICO (Patient, Intervention, Comparison, and Outcome) (9).

P (COPD OR chrocic obstructive pulmonary disease, PPOK), I (Therapy, breathing therapy, pursed lips breathing therapy, terapi pernapasan pursed lips breathing), C (Tidak ada pembanding), O (Frequency of breathing, Respiratory Rate, frekuensi pernapasan). Artikel dilakukan seleksi kerelevanan menggunakan instrument penilaian Duffy's Research Appraisal Checklist Approach.

Kriteria inklusi pada penelitian ini ialah artikel tahun 2015-2019 full text yang sesuai dengan topik penelitia yaitu teknik PLB pada pasien PPOK, terdapat ISSN dan atau DOI, artikel yang berfokus pada intervensi terapi Pursed Lips Breathing, artikel yang berfokus pada pemenuhan oksigenisasi dan frekuensi pernapasan sebagai alat ukur. Kriteria eksklusi diantaranya artikel yang tidak sesuai dengan tujuan penelitian, artikel yang bukan pasien PPOK sebagai responden.

\section{HASIL DAN PEMBAHASAN}

Pertanyaan penelitian dirumuskan melalui strategi PICO adalah sebagai berikut: Bagaimana efektifivitas teknikPursed Lips Breathing pada pasien PPOK? 
Artikel berjumlah 315 yang diidentifikasi dari 4 data literature pencarian dan dilakukan penyeleksian sesuai dengan kriteria inklusi dan eksklusi yang ditetapkan. Artikel yang eksklusi karena tidak sesuai dengan tujuan penelitian sebanyak 213 artikel, 92 artikel eksklusi karena responden bukan merupakan pasien yang menderita penyakit paru obstruksi kronis (PPOK).

Sepuluh artikel memenuhi kriteria-kriteria inklusi, dimana sepuluh artikel tersebut ditelaah secara umum baik artikel dengan keefektivan intervensi maupun artikel intervensi yang tidak efektiv. 10 artikel ini kemudian dilakukan penilaian kirtisi berdasarkan dengan instrument penilaian Duffy's Research Appraisal Checklist Approach. Tiga artikel dieksklusikan setelah dilakukan penilaian Duffy's Research Appraisal Checklist Approach karena artikel tersebut merupakan kategori average paper (skor 103-204). Sehingga terdapat 7 artikel yang memenuhi kriteria inklusi dan eksklusi serta instrument penilaian.

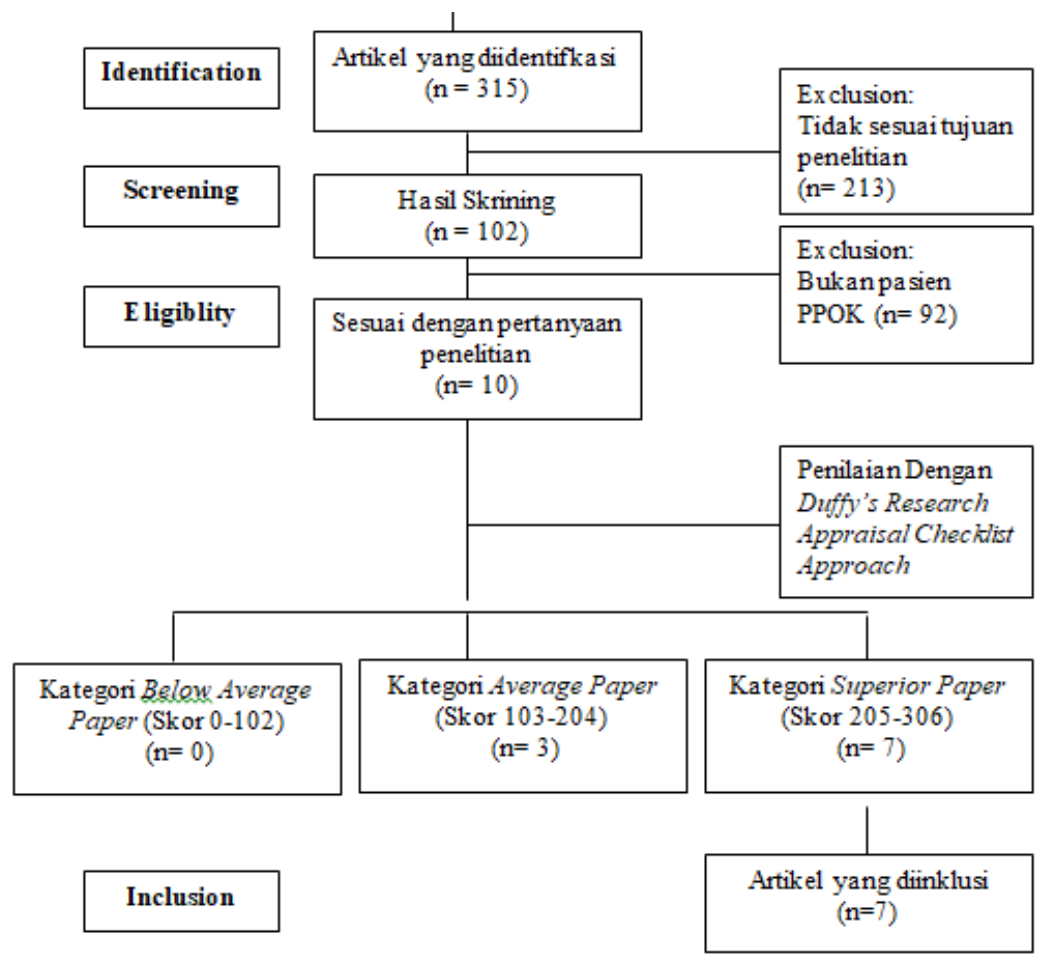

Gambar 1: Bagan Pencarian Artikel

Deksripsi 7 artikel penelitian tentang terapi pursed lips breathing menunjukkan bahwa keseluruhan hasil penelitian membuktikan adanya pengaruh terapi pursed lips breathing (PLB) terhadap manajemen pernapasan pasien Penyakit Paru Obstruksi Konis (PPOK). Diantara pengaruh yang terjadi pada pasien setelah diberikan intervensi pursed lips breathing ialah penurunan frekuensi pernapasan, peningkatan SpO2 atau saturasi oksigen, peningkatan Force Expiratory One Second (FEV1), dan sebagainya, yang dimana outcome-outcome tersebut berkaitan erat dengan proses bernapas dan proses pemenuhan kebutuhan oksigenisasi pasien PPOK. Teknik-teknik pengambilan sampel ialah dengan cara Random purposively 
sampling, quota sampling, simple random sampling, dan sampling jenuh yang merupakan pengambilan keseluruhan populasi.

Sampel yang digunakan rata-rata 8-40 orang. Sebagian penelitian melakukan pembagian kelompok intervensi dan kelompok control, beberapa penelitian lain menggunakan satu kelompok intervensi yang kemudian dilakukan penilaian data sebelum dan sesudah intervensi. Intervensi teknik pursed lips breathing rata-rata diberikan 6-30 menit selama 3 hari berturut-turut, salah satu artikel memberikan intervensi selama 6-24 minggu. Kemudian dilakukan evaluasi pengaruh intervensi pada sampel yang disesuaikan dengan tujuan masing-masing penelitian.

Teknik pernapasan pursed lips breathing memiliki banyak banyak manfaat sebagai salah satu tindakan non-farmakologi manajemen pernapasan dalam praktek mandiri keperawatan. Teknik ini mampu mengurangi frekuensi pernapasan dan meningkatkan pemenuhan oksigenasi (SpO2) pasien PPOK. Penuruan terjadinya dispnea juga dirasakan setelah melakukan teknik ini secara terus-menerus. Hal ini sejalan dengan teori teori yang mengatakan bahwa teknik pursed lips breathing dapat membantu memperbaiki frekuensi pernapasan yang abnormal pada pasien dengan PPOK, yaitu dari pernapasan yang dangkal dan cepat berubah menjadai pernapasan yang dalam dan lambat (10)

Gejala yang sering ditemukan pada pasien PPOK ialah sesak napas. Keluhan sesak napas menjadi keluhan utama yang dirasakan oleh pasien karena bersifat progresif, persisten dan bertambah berat apabila melakukan suatu aktivitas seharihari. Latihan pernapasan dengan teknik pursed lips breathing ini dapat memperbaiki keluhan sesak napas tersebut, memberikan perasaan tenang dan nyaman, meningkatkana arus puncak ekspirasi, dan mampu memperlambat frekuensi pernapasan termasuk pada saat pasien melakukan aktivitas. Latihan pernapasan dengan tehnik pursed lips breathing mampu meningkatkan volume tidal dan kekuatan otot pernapasan (11).

Hasil penelitian yang dilakukan oleh (7) menunjukkan bahwa terdapat perbedaan yang signifikan pada frekuensi pernapasan dan SpO2 pasien PPOK sebelum dan sesudah diberikan latihan pernapasaan teknik pursed lips breathing. Penelitian tersebut sejalan dengan peneltian yang dilakukan oleh (12), Teknik pursed lips breathing merupakan suatu latihan pernapasan yang terdiri dari dua mekanisme yaitu proses inspirasi secara dalam dan kuat serta mekanisme ekspirasi yang aktif dan panjang. Proses ekspirasi dikatakan normal apabila proses tersebut dilakukan dengan cara pengeluaran nafas tanpa menggunakan energi.

Penelitian yang dilakukan oleh (13), menunjukan bahwa teknik pernapasan pursed lips breathing mampu meningkatkan nilai Forced Expiratory Volume in One Second (FEV1). Teknnik pursed lips breathing dapat membantu penderita PPOK mengosongkan udara dalam paru-paru dan memperlambat laju pernapasan pasien. Pengembalian posisi digfragma yang merupakan otot pernapasan yang terletak di bawah paru-paru adalah salah satu manfaat dari teknik pursed lips breathing. Pada proses inspirasi paru-paru mengembang dan diagfragma melengkung dan bergerak ke bawah. PLB juga menyebabkan otot perut mengalami kontraksi ketika proses 
ekspirasi, sehingga diagfragma mengalami pergerakan ke atas dan membantu proses pengosongan udara dalam paru-paru,akibatnya pasien PPOK akan bernapas dengan lebih efisien dan lebih lambat (14).

Teknik pursed lips breathing mampu meningkatkan tekanan pada rongga mulut, tekanan tersebut diteruskan melalui cabang-cabang bronkus sehingga dapat mencegah kolaps dan air trapping pada saluran pernapasan kecil ketika melakukan ekspirasi, hal tersebut mampu meningkatkan nilai FEV1 (10). Pursed LipsBreathing ialah latihan pernapasan yang bertujuan untuk mempermudah proses pengeluaran udara yang terjebak di dalam paru-paru dengan cara membantu melakukan menekanan pada proses ekspirasi.

Penelitian lain dilakukan oleh (13). Peneliti mengidentifikasi perbedaan efektivitas PLB dengan sixminutes-walktest (6MWT) terhadap FEV1. Jumlah sampel dalam penelitian tersebut ialah 40 orang, kemudian dibagi dalam dua kelompok intervensi dengan masing-masing kelompok berjumlah 20 orang. Hasil analisis didapatkan bahwa pursed lips breathing lebih mampu meningkatkan nilai FEV1 daripada 6MWT. Hal ini sejalan dengan penelitian yang dilakukan oleh (15), dimana latihan pernapasan PLB dapat meningkatkan volume ekspirasi paksa detik pertama (FEV1) serta dapat meningkatkan kapasitas paru. Pursed lips breathing merupakan pernapasan melalui bibir yang dikerucutkan yang dapat meningkatkan pola pernapasan.

Rehabilitasi penyakit paru dapat dilakukan dengan melakukan latihan fisik dan latihan pernapasan, serta psikologis. Latihan fisik yang dianjurkan salah satunya ialah pursed lips breathing dengan tujuan memperbaiki ventilasi dan menyingkronkan kerja otot-otot toraks dan abdomen pada saat proses bernapas (16). Peneltian lain didapatkan bahwa pasien PPOK yang diberikan latihan pernapasan pursed lips breathing menurunkan jumlah pasien yang mengalami pola napas tidak efektif (17).

Penulis menyimpulkan bahwa teknik pernapasan pursed lips breathing mempunyai pengaruh yang signifikan terhadap perbaikan pola pernapasan dan peningkatan pemenuhan kebutuhan oksigenisasi pasien PPOK. Teknik pursed lips breathing harus dilakukan secara terus-menerus dalam keseharian pasien guna dalam usaha pencegahan terjadinya sesak dan pemulihan kondisi pernapasan. Teknik pursed lips breathing merupakan salah satu teknik pernapasan yang mudah digunakan dan tidak membutuhkan alat bantu apapun dalam proses pelaksanaannya serta memiliki pengaruh besar terhadap proses bernapas dan oksigenisasi pasien PPOK (18).

Berdasarkan uraian di atas dapat disimpulkan bahwa teknik pursed lips breathing sangat bermanfaat bagi pasien PPOK yang mengalami sesak napas dan penurunan oksigenisasi tubuh karena teknik tersebut mampu menurunkan frekuensi pernapasan serta mampu mingkatkan pemenuhan kebutuhan oksigenisasi pasien PPOK. Teknik pursed lips breathing ini mampu memberikan efek yang baik terhadap fungsi pernapasan dengan melaksanakan teknik tersebut secara teratur dan terus- 
menerus. Teknik PLB dapat dilakukan 3 kali sehari pada pagi, siang, dan sore hari dengan durasi 6-30 menit untuk mendapatkan hasil yang optimal.

Latihan pernapasan dengan teknik pursed lips breathing dapat mengurangi frekuensi pernapasan, menjadikan pola napas efektif, mengurangi sesak nafas, serta mampu meningkatkan pemenuhan oksigenisasi manusia khususnya pada pasien PPOK sehingga pasien mampu melakukan proses bernapas secara normal. Hal ini dapat dikaitkan dengan teori keperawatan tentang bernafas secara normal sebagai salah satu kebutuhan dasar manusia yang dikemukakan oleh Virginia Henderson.

Virginia Henderson dalam teorinya mengemukakan bahwa terdapat 14 kebutuhan dasar manusia yang merupakan komponen penanganan keperawatan. Penderita PPOK identik dengan terjadinya sesak napas. Sesak napas terjadi akibat adanya obstruksi saluran pernapasan sehingga pasien mengalami hambatan dalam proses bernapas. Sesak napas dapat diketahui dengan pola napas yang tidak teratur dan terjadi peningkatan pada frekuensi pernapasan. Oleh karena adanya keluhan sesak nafas tersebut, pemenuhan kebutuhan dasar manusia poin 1 yaitu bernapas secara normal yang dikemukakan oleh Virginia Henderson mengalami hambatan.

Untuk memenuhi kebutuhan bernapas secara normal sesuai dengan yang dikemukakan oleh Virginia Henderson salah satunya ialah dengan melakukan teknik pernapasan pursed lips breathing. Teknik pursed lips breathing bertujuan untuk memperbaiki ventilasi dan menyingkronkan kerja otot toraks dan abdomen sehingga pasien PPOK mampu bernapas lebih efektif dan normal serta saturasi oksigen dalam tubuh mengalami peningkatan.

\section{KESIMPULAN}

Hasil study systematic review yang telah dilakukan pada penelitian ini yaitu tentang efektivitas teknik pursed lips breathing (PLB) pada pasien penyakit paru obstruksi kronis (PPOK) dapat disimpulkan bahwa keseluruhan artikel penelitian yang menggunakan intervensi pernapasan pursed lips breathing yaitu sebanyak 7 artikel dinilai efektif, baik artikel nasional maupun internasional yang dibuktikan kerelevanan penelitian dengan beberapa penelitian lain. Terapi latihan pernapasan dengan teknik pursed lips breathing memberikan dampak positif terhadap pasien PPOK setelah mereka menggunakan terapi tersebut secara terus-menerus yaitu dalam waktu 15-30 menit sebanyak 3 kali sehari, dampak positif yang diberikan ialah salah satunya memperbaiki proses bernafas pasien sehingga pasien mampu bernapas secara normal dan oksigenisasi tubuh dapat terpenuhi dengan baik.

Teknik pursed lips breathing sangat mudah untuk dilakukan dan tidak membutuhkan tempat serta alat yang banyak. Terapi PLB dianjurkan untuk diterapkan karena sesuai dengan artikel penelitian teknik ini efektiv dan dapat dilakukan dimana saja dan kapan saja dalam keseharian pasien. Penelitian lanjutan tentang teknik ini sangat diperlukan dengan memperbanyak sampel penelitian agar hasil penelitiannya lebih representative, waktu penelitian diperpanjang supaya lebih akurat dalam meneliti subyek penelitian. 


\section{DAFTAR PUSTAKA}

1. WHO. Chronic obstructive pulmonary disease (COPD). 2017.

2. Terzikhan N, Verhamme KMC, Hofman A, Stricker BH, Brusselle GG, Lahousse L. Prevalence and incidence of COPD in smokers and non-smokers: the Rotterdam Study. European Journal of Epidemiology. 2016;31(8):785-92.

3. Black J, Hawks J. Keperawatan Medikal Bedah: Manajemen Klinis Untuk Hasil Yang Diharapkan. 8th ed. Singapore: Elsevier; 2014.

4. Singh D, Agusti A, Anzueto A, Barnes PJ, Bourbeau J, Celli BR, et al. Global Strategy for the Diagnosis, Management, and Prevention of Chronic Obstructive Lung Disease: the GOLD science committee report 2019. The European respiratory journal. 2019;53(5).

5. Riskesdas. Penyajian Pokok-Pokok Hasil Riset Kesehatan Dasar 2013. 2013;

6. Depkes Sul-sel. Profil Kesehatan Prov . Sulawesi Selatan Tahun 2016 Profil Kesehatan Prov . Sulawesi Selatan Tahun 2016. Sistem Informasi Tuberculosis Terpadu. 2016.

7. Sakhaei S, Sadagheyani HE, Zinalpoor S, Markani AK, Motaarefi H. The impact of pursed-lips breathing maneuver on cardiac, respiratory, and oxygenation parameters in COPD patients. Open Access Macedonian Journal of Medical Sciences. 2018;6(10):1851-6.

8. Singh SK, Purohit G, Lalwani GK. Effect of Ambient Air Pollution on Forced Vital Capacity of Lungs - A Case Study of Jodhpur City. 2015;3(1):15-7.

9. Boudin F, Nie JY, Dawes M. Clinical information retrieval using document and PICO structure. NAACL HLT 2010 - Human Language Technologies: The 2010 Annual Conference of the North American Chapter of the Association for Computational Linguistics, Proceedings of the Main Conference. 2010;(June):822-30.

10. Bakti AK. Pengaruh Pursed Lip Breathing Exercise Terhadap Penurunan Tingkat Sesak Napas Pada Penyakit Paru Obstruksi Kronik (Ppok) Di Balai Besar Kesehatan Paru Masyarakat (Bbkpm) Surakarta. 2015.

11. Kim JS, Lee YS. Effects of a Balloon-Blowing Exercise on Lung Function of Young Adult Smokers. Journal of Physical Therapy Science. 2012;24(6):531-4.

12. suryati I, defrimal defrimal, putri isnanini. Perbedaan Active Cycle of Breathing Technique (Acbt) Dan Pursed Lips Breathing Technique (Plbt) Terhadap Frekuensi Nafas Pasien Penyakit Paru Obstruktif Kronik (Ppok) Di Poli Paru Rsud Dr. Achmad Muchtar Bukittinggi Tahun 2018. Prosiding Seminar Kesehatan Perintis. 2018;1(2):17-17. 
13. Suryantoro E, Isworo A, Upoyo AS. Perbedaan Efektivitas Pursed Lips Breathing dengan Six Minutes Walk Test terhadap Forced Expiratory. Jurnal Keperawatan Padjadjaran. 2017;5(2):99-112.

14. Petty TL, Burns M, Tiep BL. Essentials of pulmonary rehabilitation. A Pulmonary education and research foundation publication. 2005;1-51.

15. Imania D, Tirtayasa K, Indra Lesmana S. Breathing Exercise Sama Baiknya Dalam Meningkatkan Kapasitas Vital (Kv) Dan Volume Ekspirasi Paksa Detik Pertama (Vep1) Pada Tenaga Sortasi Yang Mengalami Gangguan Paru Di Pabrik Teh Pt. Candi Loka Jamus Ngawi. Sport and Fitness Journal. 2015;3(3):38-49.

16. Silalahi KL. Pengaruh Pulsed Lip Breathing Exercise Terhadap Penurunan Sesak Napas Pada Pasien Penyakit Paru Obstruktif Kronik (Ppok) Di Rsu Royal Prima Medan 2018. Jurnal Keperawatan Priority. 2019;2(1):93-103.

17. Astuti LW. Pengaruh Pursed Lips Breathing Terhadap Pola Pernapasan Pada Pasien Dengan Emfisema. Program Studi Ilmu Keperawatan STIKES Ngudi Waluyo Ungaran. 2014. p. 1-10.

18. Roberts SE, Schreuder FM, Watson T, Stern M. Do COPD patients taught pursed lips breathing (PLB) for dyspnoea management continue to use the technique long-term? A mixed methodological study. Physiotherapy (United Kingdom). 2017;103(4):465-70. 